\title{
CHRISTELIKE WETENSKAP : SINOPSIS EN BIBLIOGRAFIE
}

"Christelike wetenskap het in Suid-Afrika 'n fel omstrede term geword. Vir sommige is dit 'n sjibbolet, die waarmerk van regsinnigheid. Vir ander die simbool van 'n neo-Calvinistiese dwaling waarmee gelowiges op 'n bedenklike wyse verdag gemaak word. Vir nog ander is dit 'n verleentheid"

Dr J H Malan in Roeping en riglyne, Junie 1974 p 6.

Wat Christelike wetenskap nie behoort te wees nie:

“'n Menslike filosofie om die persoonlike religieuse verbinding met God te vervang."

“'n Godsdienstige sisteem of ideologiese dogmatisme onder die dekmantel van wetenskap, versier met Bybeltekste."

"'n Nuwe slawerny om die vryheid in Christus in te ruil vir 'n intellektualistiese parade van skyngeleerdheid."

“'n Monopolie van een elite-kerkgroep wat Christus opeis vir Paulus, Apollos, Luther, Calvyn, Kuyper of wie ookal (vgl 1 Kor 1:12)."

“'n Tegniek ten dienste van magsmanupulasies waardeur die ideaal en ambisies van belangegroepe in die samelewing deurgeloods word."

“'n Afgeslote terrein (,sel”, „kluis", "ghetto") waardeur die roeping om christelike wetenskap te beoefen by die hekke van die P U vir C $\mathrm{H} O$ eindig."

P U Studentesakboekie 1974 p 13 
Dit is vandag gelukkig nie meer nodig om apologetiesverskonend oor Christelike wetenskapsbeoefening te handel nie. Tog is dit nog steeds nodig om allerlei misverstande in die verband uit die weg te ruim en te sê wat 'n Christelike wetenskapsbeoefening nie is nie. Aangesien elkeen van die stellings waaruit hierdie kort sinopsis bestaan met die verwerping van ' $n$ bepaalde gedagte i $v$ m Christelike wetenskap begin, mag die konklusie getrek word dat Christelike wetenskapbeoefening 'n negatiewe bedryf is wat sy bestaansgrond alleen in die ontkenning vind. Dat dit 'n foutiewe gevolgtrekking sou wees, blyk egter uit die kort verduideliking na elke stelling. Deur eers te sê wat iets nie is nie, kan dik wels duideliker gestel word wat dit wel is!")

Hierdie sinopsis wil stellenderwys probeer saamvat wat verskillende voorstanders van 'n Christelike wetenskapsbeoefening tot dusver na vore gebring het. Sonder dat op volledigheid of indringende bespreking van die probleme aanspraak gemaak word, sal gepoog word om enkele kernpunte waarom dit gaan, te stel..$^{2}$ )

Die literatuurlys ${ }^{3}$ - waarin veral op Suid-Afrikaanse bydraes gekonsentreer is - bied geen volledige bibliografie nie, maar wil alleen'n vertrekpunt bied vir diegene wat die saak diepgaander wil bestudeer.

Hierdie beskeie artikeltjie word geskryf op die vooraand van 'n groot gebeurtenis vir Suid-Afrika en vir die Potchefstroomse Universiteit in die besonder: ' $n$ internasionale konferensie vanaf 9 - 13 September van gereformeerde universiteite, ander hoër onderwysinrigtings, instellings, organisasies en individue wat 'n Christelike wetenskapsbeoefening by die lig van die Woord van God voorstaan.") Mag hierdie klein vonkie tesame met die fakkels wat vanaf oor die hele werreld na Potchefstroom gebring sal word, uitgroei tot 'n vlammesee waarvan die lig ver en wyd oor die akademiese wêreld sal uitstraal!

\section{SINOPSIS}

Die oorsig bestaan uit die volgende tien stellings:

1. Christelike wetenskapsbeoefening verwerp die houding van sommige Christene wat beweer dat dit wel 
moontlik is om as Christen (ook) wetenskap te beoefen, maar dat dit nie moontlik is om Christelike wetenskap te beoefen nie. Sodanige Christene noem hulleself wel Christen-wetenskaplikes, maar weier om van Christelike wetenskap te spreek.

Hierteenoor stel ons dat Christelike wetenskap nie bloot wetenskaps-beoefening deur Christene is nie, maar Christelike beoefening van die wetenskap. Teenoor die idee van sommige, $\mathrm{nl}$ dat wat Christelik aan 'n Christelike wetenskap is nie wetenskap is nie, en wat wetenskaplik aan 'n Christelike wetenskap is nie Christelik is nie, handhaaf ons dat Christelike wetenskap nie net wetenskap van CHRISTENE is nie, maar ook deeglik Christelike WETENSKAP.

Terwyl sommige wetenskap en Christenwees skei, sien ander Christelike wetenskap weer as 'n vanselfsprekendheid as die wetenskaplike kenner 'n Christen is. Dit is egter nie so eenvoudig nie aangesien baie mense wel Christelik in hul nie-wetenskaplike bestaan mag wees, maar beslis nie in hul wetenskapsbeoefening nie. Om 'n werklike Christelike wetenskapsbeoefening te hê, moet die Christen doelbewus en met volharding ook in sy wetenskaplike aktiwiteit na gehoorsaamheid aan God en Sy Woord streef. Die weg van die scientia reformata is nie 'n weg van maanskyn en rosegeur nie, maar van voortdurende stryd - ook teen jouself.

2. Ook die houding van sommige wat beweer dat alleen sekere wetenskappe Christelik kan wees, is onaanvaarbaar. Volgens hierdie standpunt sou Wysbegeerte, Teologie en die sg "menswetenskappe" wel 'n Christelike karakter kan openbaar, maar beslis nie die natuurwetenskappe nie.

Hierteenoor handhaaf ons dat alle wetenskappe Christelik beoefen kan word. Dit is wel so dat, oppervlakkig beskou, soms nie dadelik die verskil tussen 'n Christelike en nie-Christelike Wiskunde merkbaar is nie. As die argument egter aangevoer word dat vir beide die gelowige Christen en die sg "ongelowige" wiskundige $2 \mathrm{x}$ $2=4$ is, dan is die Christelike en nie-Christelike wetenskap nog maar taamlik bolangs vergelyk. Wanneer dieper ondersoek ingestel word en bv na die grense, die doel en sin van die Wiskunde gevra word, sal die verskil 
wel terdeë blyk. Die verskillende onderdele van die wetenskap moet daarom in die breër verband van die geheel van die betrokke wetenskap gesien word. Dan sal duidelik word dat, al lyk dit of twee wetenskaplikes ('n Christelike en nie-Christelike) presies dieselfde beweer, hulle tog nie dieselfde sê nie! Die Christelike wetenskaplike sal bv met die stelling $2 \times 2=4$ uitdrukking wil gee aan die wetmatighede wat God in die skepping gestel het, terwyl die Rasionalistiese Wiskundige daarmee bedoel dat die mens hierdie stelling vanuit sy vergoddelikte rede aan die werklikheid oplê.

3. Die werklike Christelike wetenskapsbeoefening verwerp ook die neutraliteitsgedagte. Hierdie gedagte is onaanvaarbaar nie alleen omdat dit mense is wat wetenskap beoefen nie ('n mens kan nooit neutraal wees nie), maar ook omdat neutraliteit 'n verloëning van die Woord van God en die God van die Bybel sou beteken. 'n Neutrale tussenposisie is 'n onmoontlikheid: "Wie nie vir My is nie, is (ook in die wetenskapsbeoefening) teen My". Verder gaan die redes wat vir 'n neutrale beoefening van die wetenskap aangevoer word ook nie op nie.

Gewoonlik word aangevoer dat wetenskap 'n neutrale aangeleentheid is omdat dit alleen met die meetbare, weegbare, telbare en sigbare feite te make het. Hierteenoor stel die Christenwetenskaplike dat dit 'n baie eensydige (en dus bevooroordeelde!) wetenskapsidee is wat glo dat die wetenskap alleen met die sigbare, meetbare en telbare te make sou hê. Verder vorm feite, self 'n feitemassa, op sigself nog geen wetenskap nie. Feite word volgens 'n bepaalde visie geselekteer en geïnterpreteer voordat werklike wetenskap tot stand kom. Selfs in 'n hipotese (bv die van die Evolusionisme) moet eers geglo word - anders sou dit sinloos wees om feite te probeer versamel om dit te bewys.

Verder word beweer dat wetenskap neutraal is aangesien dit niks te make het met norme, wardes, beginsels, voorveronderstellings ens nie. Wetenskap moet onpartydig, onbevooroordeeld, sonder voorveronderstellings, saaklik en objektief wees. 'n Christelike wetenskap sou hiervolgens op partydige vooringeno menheid berus en nie op eie selfstandige ondersoek, redenering en kennis nie sodat dit as oneerlik en eensydig bestempel moet word. 
Ons antwoord hierop is dat die voorstanders van die neutraliteitsidee in hulle eie swaard val. Hulle is dan ook nie eerlik nie aangesien ook hulle in sekere voorveronderstellings glo wat hulle nie met sg "feite" kan bewys nie. Hulle kan byvoorbeeld nie bewys dat die werklikheid bloot 'n meet-, weeg- en telbare werklikheid is nie. Hierdie mense kan nie eers hulle stelling dat die wetenskap neutraal moet wees (met feite) bewys nie. As hulle beweer dat die wetenskap met geen voorveronderstellings beoefen mag word nie, mag hulle ook nie vereis dat dit neutraal beoefen moet word nie. Neutraliteit is ook 'n beginsel, die "beginsel van beginselloosheid"! Dit is heel maklik om aan te toon dat die neutraliteitsidee 'n dogma is en wel 'n dogma wat die eie standpunt (nl neutraliteit) as absoluut handhaaf terwyl alle ander standpunte (veral die Christelike) daarvolgens verwerp word. Die voorstanders van die ntutrale wetenskapsbeoefening is dan ook nie so liberaal en ruimhartig soos meestal voorgegee word nie, maar dikwels uiters bekrompe en onverdraagsaam teenoor al diegene wat nie hulle eie standpunt deel nie.

Die Christelike wetenskaplike maak duidelik tussen objektiwiteit en neutraliteit in die wetenskaplike aktiwiteit onderskeid: eg is noodsaaklik, maar lg is onmoon tlik.

4. 'n Christelike wetenskap is dus nie by voorbaat 'n gediskwalifiseerde wetenskap omdat dit "met oogklappe" vanuit 'n geloofsstandpunt sou uitgaan nie. Die Christelike wetenskaplike is juis eerlik en oop omdat dit bewustelik vanuit 'n bepaalde standpunt wetenskap beoefen en dit ook erken en nie probeer verdoesel nie. Die oortuigde Christen probeer nie om neutraal te wees wanneer hy sy sondagpak vir die laboratoriumjas verruil nie! Hy erken dat sy geloof ook sy wetenskaplike werk (soos die res van sy lewe) deursuur en nie soos 'n klip onopgelos in 'n koppie koffie lê nie. Die Christenwetenskaplike voer nie 'n skisofrene bestaan omdat hy 'n kloof tussen sy lewens- en wêreldbeskouing en wetenskap ervaar nie, die verband tussen lewensbeskouing en wetenskap is vir hom vanselfsprekend. Die voorwetenskaplike kennis (insluitende sy geloofskennis) wat sy wetenskap bepaal en rig is vir hom nie minderwaardige kennis teenoor die wetenskaplike kennis nie, maar kennis van 'n ander aard wat net so goed as wetenskaplike kennis bestaansreg het. 
Aangesien wetenskap die resultaat is van die wetenskaplike kenaktiwiteit van die kenner wat op 'n spesifieke veld gerig is, word alle wetenskappe enersyds bepaal deur die religeuse gerigtheid van die hart (vir of teen God of halfslagtig - soos in die sintesedenke) van die wetenskaplike en andersyds deur die veld van ondersoek.

Alle menslike aktiwiteite - ook kenaktiwiteite - is harteaktiwiteite, is religieus bepaalde, voorwetenskaplike "bril" van sy eie werklikheidsvisie. Aangesien elke mens se visie op dit wat bestaan religieus gekleurd is, staan dit in die geval van die Christen nie los van sy Skrifgeloof nie. Verder word die veld in die geval van 'n Christelike wetenskapsbeoefening (voorwetenskaplik) deur die Woordopenbaring van God verlig.

Om twee redes verskil die wetenskapsbeoefening van die Christen en die nie-Christen dus ook al sou hulle dieselfde voorwerp bestudeer: die Christenwetenskaplike beoefen sy wetenskap met 'n deur God aangegrype hart en doen dit $t \mathrm{o} v$ 'n deur God se Woord verligte veld van ondersoek.

5. Die Christelike wetenskapsbeskouing beskou ook die moderne Historisme en Relativisme as 'n vyand. Die kontemporêre Historisme en Irrasionalisme glo nie meer aan die neutraliteitsgedagte nie, maar is daarom nog geen vriend van 'n Christelike wetensk apsbeoefening nie aangesien dit die historiese verandering oorbeklemtoon en alles gerelativeer word sodat geen absolute waarheid meer moontlik is nie. Die Christelike wetenskapsbeoefening erken wel dat wetenskapsbeoefening - insluitende Christelike wetenskap - feilbare, tydsgebonde menslike aktiwiteit is, maar weier om dieselfde van die woord van God te aanvaar. Die Christenwetenskaplike onderken ook die onontwykbare dilemma van alle historistiese denke: die historis moet of konsekwent wees en erken dat sy dogma (nl dat alle waarheid relatief is) ook relatief is en so die slagoffer van sy eie leerstelling word, of inkonsekwent wees (wat gewoonlik die geval is) en leer dat alle ander "dogmas" behalwe sy eie standpunt van relatiewe waarde is.

6. 'n Werklike Christelike wetenskapsbeoefening verwerp die geloof-wete-dilemma in al sy gedaantes. Die belangrikste standpunte $\mathrm{m}$ b t die verhouding tussen geloof en wete wat verwerp word, is o a die volgende ${ }^{5}$ ): 
(a) dat die (Christelike) geloof die wetenskap oorbodig sou maak;

(b) dat die wetenskap die (Christelike) geloof oorbodig maak;

(c) dat beide geloof en wetenskap bestaansreg het ook al weerspreek hulle mekaar (leer van die dubbele waarheid ${ }^{6}$ );

(d) dat die geloof sou begin waar die wetenskap nie verder kan nie.

Dit moet beklemtoon word dat nie alleen die standpunt van "of geloof of wetenskap" vir ons onaanvaarbaar is nie, maar ewe goed die standpunt van "en geloof en wetenskap" aangesien in albei gevalle na 'n oplossing binne dieselfde valse dilemma gesoek word sonder om die dilemma self te bevraagteken. Die standpunt van "geloof en wetenskap" (of "wetenskap en geloof") is dus nie minder gevaarlik as die van "geloof of wetenskap" nie. Eersgenoemde standpunt skei ook eers geloof en wetenskap en probeer hulle daarna integreer. Die integrasie van geloof en wetenskap is egter 'n valse uitgangspunt omdat aan elke wetenskap reeds ' $n$ bepaalde geloof (Christelik of nie-Christelik) ten grondslag lê.

Die vraag is nie of en hoe wetenskap en geloof harmonies kan saamgaan nie, maar watter geloof die wetenskap bepaal. Teenoor die standpunte van "geloof of wetenskap" en "geloof en wetenskap" stel ons dus die van "gelowige wetenskap"!

In die verband moet selfs versigtig met die benaming "Christelike wetenskap" omgegaan word ${ }^{7}$ ) aangesien dit vir verskillende persone nie dieselfde mag beteken nie. Vir diegene wat nog steeds van die tweeterreine-leer van natuur en genade uitgaan, is Christelike wetenskap die optelsom van wetenskap (op die terrein van die natuur) en "Christelikheid" (op die terrein van die genade). Of en op die wyse staan sekere moderne Rooms-Katolieke denkers ook 'n "Christelike" wetenskapsbeoefening voor - die wetenskap (op die laere terrein) word van uit die Christelike geloof (op die hoëre vlak van die genade) gekersten of gechristianiseer. Op hierdie wyse word geen radikaal-Christelike wetenskap ( $\mathrm{d}$ w $\mathrm{s}$ Christelik vanuit die wortel) gebou nie, maar word alleen 'n Christelike 
suikerlagie oor iets wat in wese nie Christelik is nie gestrooi.

Christelike wetenskapsbeoefening beteken nie iets Christeliks in, aan of apart by die gewone wetenskapsbeoefening nie. Die "Christelike" van Christelike wetenskap impliseer nie 'n bloot statiese Christelike grondslag as onderbou, of 'n teologiese bo-bou (tweede verdieping) of 'n filosofiese meta-verdieping nie.

Baie dink nog dat hulle met egte Christelike wetenskapsbeoefening besig is wanneer hulle, nadat hulle feitlik die hele pad met die nie-Christen wetenskaplike saamgeloop het, agteraf 'n paar Christelike gedagtes na vore bring. Aan die einde word dan 'n paar korreksies aangebring of kanttekeninge (soms ook nog alleen deur Bybeltekste aan te haal) by die nie-Christelike wetenskap geplaas. $R e g$ van die begin af, vanuit die wortel moet die wetenskap egter "in U lig" beoefen word - anders is dit niks anders as 'n brousel met 'n Christelike sousie daarby om dit verteerbaarder te maak nie.

7. Dit is vervolgens van belang om te stel dat Christelike wetensakp nie dieselfde as verteologiseerde wetenskap is nie. Sommige huldig nog steeds die idee dat Christelike wetenskap 'n soort huwelik tussen Natuurwetenskap en Teologie is. Vir diegene impliseer wetenskap "in U lig" dat ' $n$ mens behalwe as fisikus, sielkundige en opvoedkunde ook die rol van teoloog moet speel. Andere weer huldig die idee dat Christelike wetenskap'n wetenskap is wat onder die plak van die Teologie gebuk gaan of 'n blote agterryer van die teologiese wetenskap sou wees.

Hierdie misverstand is wel te begrype uit die feit dat die Woord van God gewoonlik as die veld van ondersoek van die Teologie beskou is. Dit sou egter verkeerd wees om die Bybel die monopolie van een bepaalde wetenskap, $n l$ die Teologie te maak. Die woord van God mag nie uitsluitlik aan een wetenskap toegesê word nie aangesien God daarin openbaringe aangaande die hele werklikheid makk wat die weienskaplike aktiwiteit van alle wetenskaplikes rig en lei. Elke wetenskaplike behoort die Bybel so te ken dat hy die lig wat dit op sy spesifieke veld bied, kan gebruik. Dit is dus verkeerd om die Christelikheid van alle wetenskappe van net een (die Teologies) af- 
hanklik te maak. Elke wetenskap moet sy veld van ondersoek in die helder lig van God se Woord bestudeer en nie in die (vandag dikwels flou) liggie van die Teologie nie. Veral nog as in gedagte gehou word dat die Teologie feilbare mensewerk is en nie 'n vanselfsprekende Christelike wetenskap is nie - daar is seker net soveel, indien nie meer, heidense as Christelike teologieë! Moontlik lê agter die standpunt dat die ander wetenskappe alleen via die Teologie (by wyse van leenstellings of wat ookal) Christelik kan wees nog die foutiewe gedagte dat die veld van ondersoek (in geval van die Teologie dan die Bybel) 'n wetenskap Christelik maak.

8. Egte Christelike wetenskapsbeoefening verwerp vervolgens 'n biblisistiese houding. Uit wat hierbo (punt 7) gestel is, mag nie die gevolgtrekking gemaak word dat die Christelike wetenskaplike bloot woordeliks herhaal wat in die Bybel staan nie. God het Sy Woord nie gegee om net nagepraat te word nie, maar dit moet onder leiding van die Heilige Gees met erns bestudeer en deurdink word sodat gevolgtrekkinge vir die wetenskapsbeoefening gemaak kan word. Om i p v die mens self te bestudeer en (as antropoloog) die wette vir die menslike bestaan te ontdek, niks meer i v m die mens te wil sê as wat die Heilige Skrif in soveel woorde oor hom openbaar nie, sou Biblisisme en geen Christelike wetenskapsbeoefening beteken. Die Christen-wetenskaplike degradeer die Bybel nie tot handboek vir die wetenskap nie.

In die verskillende wetenskappe word veral die wette wat vir verskillende aardsgeskape dinge en/of terreine geld opgespoor. Hierdie wette is die uitdrukking van God se wil vir die geskape dinge. Daarom is die Bybel ook noodsaaklik want God se wil vir sy skepsele kan alleen by die lig van sy Woord korrek gesien word. Die Christelike plantkundige of dierkundige sal bv moet nagaan wat God in sy Woord aangaande hulle spesifieke velde van ondersoek openbaar. Hiermee word nie bedoel dat die velde van ondersoek vir byvoorbeeld die Plantkunde (sê 'n spesifieke boomsoort) of die Dierkunde (bv 'n padda) nie belangrik is nie en dat wetenskaplikes op hierdie gebiede alleen Bybeltekste wat oor die sekere boomtipe of oor paddas iets sê, moet nagaan om op "Christelike wetenskapsbeoefening" aanspraak te kan maak nie! Dit is verskriklike karikatuurbeeld van wat wetenskapsbeoefening "in U lig" werklik wil wees. 
9. Die oortuigde Christenwetenskaplike verwerp verder die gedagte dat Christelike wetenskap sou pretendeer dat dit alleen die warheid in pag sou hê. Hoewel sy wetenskap by die lig van Gods Woord beoefen word, begryp die Christenwetenskaplike dikwels nog so min van die betekenis van die Bybel vir sy wetenskaplike aktiwiteite. Hy erken - dalk meer as die nie-Christen die gebrekkigheid en beperktheid van sy insigte omdat hy weet van die verduistering van die sondeval. $\mathrm{Hy}$ is steeds bereid tot selfkritiek en sal nimmer sy eie resultate as die laaste woord beskou nie en ook nie toelaat dat die beskouinge van mede-Christenwetenskaplikes nagepraat of gekanoniseer word nie. Scientia reformata est semper reformanda!

10. Nie a g v die grootsheid van eie prestasies nie, maar a g v die seënende hand van die Here kan die Christenwetenskaplike vandag ook die idee verwerp dat Christelike wetenskap 'n blote ideaal is en sal bly. Werklike Christelike wetenskapsbeoefening het veral gedurende die afgelope paar dekades ' $n$ werklikheid op talle gebiede geword. Om dit te staaf, sou na die verassende insigte op die gebied van verskillende dissiplines verwys moes word - iets wat buite die bestel van hierdie kort sinopsis val.

Mag die vrugte wat reeds opgelewer is nie tot gevolg hê dat ons op ons louere gaan rus nie, maar eerder as aansporing dien om onsself met nog groter erns en toewyding te gee vir die moeilike maar ook boeiende en heerlike roeping van wetenskap te beoefen en te doseer wat tot verheerliking van God mag dien en mag bydra tot die koms van Sy koninkryk!

B J VAN DER WALT

PU VIR CHO 


\section{OPMERKINGS}

1. Die hierbo gesiteerde omskrywing uit die PU Studentesakboekie van 1974 word op p 12 vocrafgegaan deur die volgende flitsgedagtes oor wat Christelike wetenskapsbeoefening wel behoort te wees:

Resultaat van feilbare menslike denkarbeid wat God se werke ondersoek en interpreteer tot Sy eer en heerlikheid (Rom 11, 36).

Die Evangelie van Jesus Christus as krag (Grieks: dunamis) is die dinamiet om die menslike verstand nuut te maak tot kritiese onderskeiding en insig.

Vry om altyd die waarheid te ondersoek en die valsheid en verkeerde resultate te ontmasker.

Christelike wetenskap ontspruit uit 'n werkgemeenskap van belydende en getuigende christene wat bereid is om Christus na te volg (Mat 16, 24) en in die lig van die Heilige Skrif die ryke struktuur van God se skepping te ontdek en te beheers (Ps 8).

Gestimuleer en gedra deur die samolewing, maar ook noodsaaklik vir die onderwys en sy toepassinge tot seën plaaslik en landelik, vir kerk, volk, staat, ens.

Die resultate van die christelike wetenskap is ter beskikking aan die hele wêreld, God se wêreld wat nog deur die sondeval in groot nood verkeer.

2. Die gedagte is om na hierdie algemene inleiding later op sekere punte by wyse van aparte artikels dieper in te gaan.

3. Die aandag word hier daarop gevestig dat dr D Kempff in opdrag van die Departement Interfakultêre Wysbegeerte aan die PU vir CHO reeds vanaf Julie 1973 met bibliografiese navorsing oor Christelike wetenskap besig is. Die kontrole van die boeke-besit in die Ferdinand Postma Biblioteek van die PU vir CHO het reeds sover gevorder dat in die biblioteek eersdaags ' $n$ aparte katalogus "Christelike Wetenskap" geraadpleeg sal kan word wat navorsing op hierdie gebied, baie sal vergemaklik. Daar is reeds ook begin met die opstel van 'n katalogus van tydskrifartikels wat oor die onderwerp handel.

4. Besonderhede oor hierdie byeenkoms kan verkry word van die skrywer hiervan, Instituut vir die Bevordering van die Calvinisme, PU vir CHO, Potchefs troom 2520. Referate tydens hierdie konferensie gelewer, sal deur die IBC gepubliseer word.

5. Sien bibliografie vir verskillende werke en artikels in die verband.

6. Sien bibliografie vir verskillende werke en artikels in die verband. 
7. Persoonlik verkies ek liewer die benaming "Skrifmatige" of "Skrifbeligte" wetenskap. Vir breëre motivering vir die keuse van hierdie terminologie vgl my proefskrif (PU vir CHO, 1974) Die Natuurlike Teologie met besondere aandag aan die visie daarop by Thomas van Aquino, Johannes Calvyn en die "Synopsis Purioris Theologiae", p 63-65. 


\section{BIBLIOGRAFIE}

J Adler, Die wetenskap en die Bybel, Die Gereformeerde Vaandel 1,6 , Junie $1933 \mathrm{p} 215 \mathrm{ev}$.

H Bavinck, Christelijke Wetenschap, J H Kok, Kampen 1904. H Bavinck, Het Calvinisme en de wetenschap, In: Het Calvinisme. J H Kok, Kampen p 97-126

J H Bavinck, De vreugde van de wetenschap \& de tragiek van de wetenschap, Horizon 13, $1950 \mathrm{p} 246$ ev en $285 \mathrm{ev}$.

J H Bavinck, Geloven en kennen, Geref Weekblad 6, 1952 p 329 ev.

G C Berkouwer, Geloof en vooroordeel, Bezinning 6, $1951 \mathrm{p} 141 \mathrm{ev}$.

G C Berkouwer, Christian Faith and Science, Free University Quarterly 4, 1, Nov 1955 p 3-10.

G C Berkouwer, Sacrificium intellectus, Gereformeerd Theologisch Tijdschrift 68, 1968 p 177-200.

W Betzendörfer, Die lehre von der zweifachen Wahrheit bei Petrus Pomponatuis, G Schnürlen, Tübingen 1919.

W Betzendörfer, Die Lehre von der zweifachen wahrheit. Ihr erstmalige Auftreten im Christliche Abendland und ihre Quellen. Ein Beitrag sur Geschichte der Religionsphilosophie - als ob, Osiander'schen Buchhandlung, Tübingen 1924.

W Betzendörfer. Glauben und Wissen bei den grossen Denkern des Mittelalters, Leopold Klotz Verlag, Gotha 1931.

M E Botha. Neutraliteit versus normatiwiteit in die Sosiologie, Studiestuk $\mathrm{nr} 75$, Sept 1973 van die Instituut vir die bevordering van die Calvinisme, Potchefstroom 1973.

M E Botha. Christelike wetenskap met enkele illustrasies in die Sosiale Wetenskappe, Perpektief 12 nr 2 en 3, Junie 1973 p 2-23. $Q$ Breen, The twofold truth Theory in Melanchton, In: Christianity and Humanism W B Eerdmans. Grand Rapids 1968 p 69-92.

W J de Klerk, Die noodsaaklikheid van 'n lewens- en wereldbeskouing en die mensbeskouing by die beoefening van wetenskap en beroep, In: Besinning en Uitsig, 'n Keur uit die referate gelewer tydens die eeufeesjaar van die PU vir CHO en die Teologies Skool, 1969 p 47-55.

J D Dengerink, The necessity of Christian Universities, International Reformed Bulletin $8 \mathrm{nr} 23$, Okt $1965 \mathrm{p} 23 \mathrm{ev}$.

G F de Vos Hugo, Christelike regswetenskap, Tydskrif vir Christelike Wetenskap $1 \mathrm{nr} 1$.

C J Dippel \& J M de Jong, Geloof en Natuurwetenschap 1, Scheppingsgeloof natuur natuurwetenschap, Boekcentrum, 'S-Gravenhage 1965.

C J Dippel, H C van der Hulst e a, Geloof en natuurwetenschap 2 Wijsgerige en etische aspecten van de natuurwetenschap, Boekencentrum, 'S-Gravenhage 1967.

$\mathrm{H}$ Dooyeweerd. The secularization of science, International Reformed Bulletin 9, 26, 1966 p 2-17.

P G W du Plessis Christelike mediese wetenskap, Perspektief 1,3

p 1. Christelike wetenskap tersyde?, Perspektief 1, 4 p 2. Versuiling en Christelike wetenskap, Perspektief II, 1 p 1 . Sekularisasie en Christelike wetenskap, Perspektief II, $2 \mathrm{p} 1$.

B Duvenage, W J de Klerk \& J H van Wyk, Die Christelike Wetenskap, In: Roeping en Werklikheid, Potchefstroom Herald, Potchefstroom 1973 p 262-291.

D C S du Preez, Die universiteit met die Bybel, Koers 23 1955/'56 p $118 \mathrm{ev}$. 
B Duvenage, Christelike Wetenskap, In: Truth and reality, De Jong. Johannesburg 1971 p 95-108.

J Francke, Het vooroordeel in de wetenschap, Groningen, Uitgeverij de Vuurbaak 1971.

E Gilson, Reason and revelation in the Middle Ages, New York, Charles Scribner's 1952.

H Gollwitzer \& W Weischedel, Denken und Glauben Ein Streitgesprach, Stüttgart, W Kohlhammer 1965.

M Grabman, Augustins Lehre von Glauben und Wissen und ihr Einfluss auf das mittelalterliche Denken, In: Mittelaiterliches Geistesleben, München, Max Heuber 1936 II p 35-62.

T J Haitjema, Augustinus' wetenschapsidee. Bijdrage tot de kennis van de opkomst der idee eener Christelijke wetenschap in de antieke wereld, Utrecht. Van Druten 1917.

$E$ P Heideman, The relation between revelation and reason in $E$ Brunner and H Bavinck, Assen, Van Gorcum 1959.

K Hein, Zur Geschichte des Satzes van der doppelten Wahrheit. Studien zur systematische Theologie, 31, 1, 16, 1918.

$\mathrm{J}$ Hessen, Wissen und Glauben, München, E Reinhardt 1959.

P de B Kock, Die Christelike Wetenskap, Die Geref Vaandel jrg VIII 1940 p 82, 159 en 174.

$P$ de B Kock, Neutraliteit en die student, Die Gereformeerde Vaandel jrg VI 1938 p 215 en p 239.

J J Louet Feisser ea, De Christen-Academicus en de Wetenschap, Amsterdam, W ten Have 1949.

K Löwith, Wissen und Glauben, In: Augustinus Magister, Paris Etudes Augustiniennes 1954 p 403-10.

J H Malan, Christelike Wetenskap: wat sê die Skrif? Roeping en Riglyne 22, 2, Junie 1974 p 6, 7 en 11.

$M$ Maret, Weteschap en Geloof, Annalen van het Thijmgenootschap 56, 1969, 105-14.

M Maywald, Die Lehre van der zweifachen Wahrheit, Berlin, F Henschel 1871.

Medelingen van de vereniging voor Calvinistische Wijsbegeerte: volgende uitgawes: Junie 1949, Sept 1952, Mei 1956, Mei 1960.

J P A Mekkes, Geloof en Kennen, Mededelingen Sept 1952.

J P A Mekkes, Gods Woord in de wetenscahpsbeoefening, Lucerna 6, 2-16 \& 35-9 1965 .

J Möller, Glauben und Denken im Widerspruch?, München, Erich Wewel Verlag 1963.

C Muller, Science and faith: Co-existence or synthesis?, Louvain, Nauwelaerts 1962.

C K Oberholzer, Resensie van H J Strauss se boek Christelike Wetenskap, Die Hervormer Sept 1954.

A Th Peperzak ea, Geloven en weten \& Gedachtenwisseling over de zin van geloven binnen de kring der wetenschappen, Annalen van het Thijmgenootschap 56, 78-104 \& 115-36 1969.

M Pine, Pomponazzi and the problem of "double truth", Journal of the history of ideas 29, 163-93 1968.

F J M Potgieter, Prinsipiële verantwoording $t$ o v Christelike opvoeding. Christelike opvoedkunde en Christelike onderwys.

F J M Potgieter, Universiteit op teosentriese grondslag, Die Geref Vaandel jrg XXIV nr 2 Junie 1955.

I F Retief, Christelike wetenskap, Die Geref Vaandel jrg XII 1944 p $12 \mathrm{ev}$.

N H Ridderbos, Een universiteit met de Bijbel, Bezinning jrg XVIII 51963. 
P J Roscam Abbing \& A S van der Woude reds, Grensgesprekken Evangelie en wetenschappen, Kampen, Kok 1969.

H E Runner. The relation of the Bible to learning, In: Christian Perspectives 1960, Pella Iowa, Pella Publishing Co 1960 p 85-159. H E Runner, Scientific and pre-scientific, In: Christian Perspectives 1961, Hamilton Ontario, Guardian Publishing Co 1961 p 1152.

F Sassen, Boëthius van Dacië en de theorie van de dubbele waarheid, Studia Catholica 30, 262-73 1955.

H J Schutte, Christelike wetenskapsbeoefening, Bulletin van die $S A V C W 1,1,19-241965$.

$H$ J Schutte, Die gees en rigting van 'n universiteit, Bulletin van die $S A V C W 17,37-51$ Febr 1969.

$P$ G Schrotenboer, The Christian student in the modern university, International Reformed Bulletin VIII 23 Okt $1965 \mathrm{p} 14 \mathrm{ev}$. CSeerveld, A reformed Christian College, Perspektief 1, 4, 1962 p 4 ev.

J J Snyman, Diskussie-aantekeninge oor Christelike Wetenskap, Bulletin van die $S A V C W 43$ p 26-32 Des 1974.

W J Snyman, Christelike Wetenskap I Bygeloof verdryf, maar nie die geloof, Woord en Daad 10, 73, 1-2 Sept 1968.

W J Snyman, Christelike wetenskap II Verlossing 'n te swa re taak vir die wetenskap, Woord en Daad 11, 78, 8-9 Febr 1969.

W Stanford Reid, The Christian Professor in the Secular University. International Reformed Bulletin VIII 23 Okt 1965 p 5 ov.

H G Stoker, Scriptural faith and the persuit of science, $32 \mathrm{p}$ mimeograph translation by dr $\mathrm{N}$ Lee.

H G Stoker, Christelike wetenskap, Koers 17, 1, Aug 1949 p 1-9.

H G Stoker, Die Bybel en die wetenskap, Die Gereformeerde Vaandel 1, 7, Julie 1933 p 248 ev, en nr 8 Aug 1933 p 288 ev.

H G Stoker, Christelike wetenskap, Die Gereformeerde Vaandel 18, 2, April 1950 p 29 ev, en 4 Okt 1950 p 19 ev.

H G Stoker, Christelike natuurwetenskap, Koers 1319454 p 149 ev.

H G Stoker, Christendom en wetenskap, Pretoria, Van Schaik 1929.

H G Stoker, Christelike Wetenskap, In: Beginsels en metodes in die wetenskap, Potchefstroom, Pro Rege-Pers 1961 p 299-304. H G Stoker, Christelike wetenskap, Bulletin van die SA VCW2, 1, Febr 1966 p 36-42.

H G Stoker, Christelike wetenskap - 'n noodwendigheid, In: Die atoomeeu - "in U lig", Potchefstroom, Instituut vir die bevordering van die Calvinisme, 1969 p 239-253.

H G Stoker, Die ensiklopediese vraagstuk van die beoefening van Christelike wetenskap, In: Oorsprong en Rigting II, Kaapstad, Tafelberg 1970 p 45-122.

H G Stoker, Christelike Opvoedkunde en sy plek in die sisteem van 'n Christelike Wetenskap, Studiestuk nr 8 van die Christelike Opvoedkundevereniging van $\mathbf{S} \mathbf{A}$.

H G Stoker, Wetenskap en religie - 'n wysgerige besinning, In: Jahrbuch Altstudentenverband des Deutsch-Afrikanische Studentenbundes der Universitat Pretoria 1971.

H J Strauss, Christelike wetenskap, Bloemfontein, SACUM 1953

H J Strauss, Teenstander van de Christelike wetenskap; 'n antwoord aan C K Oberholzer van U Pn a v'n resensie van Strauss se "Christelike Wetenskap", Die Gereformeerde Vaandel 24, 2, Junie 1955 p $13 \mathrm{ev}$ 
H J Strauss, Christelike lewens- en wêreldbeskouing, Bloemfontein, SACUM 1964.

H J Strauss, Christelike wetenskap en Christelike onderwys, Bloemfontein, SACUM 1964.

J A L Taljaard, "Christelike" wetenskap, Perspektief 12, 2/3, Junie 1973 24-28.

A Troost, Evangelie en economische wetenschap, In: Grensgesprekken Evangelie en wetenschappen, Kampen, Kok 1969 p 140-149.

$H$ van der Laan, A Christian appreciation of physical science, Hamilton, Ontario, A R S S 1966

N T van der Merwe, Op weg na 'n Christelike Logika, M Averhandeling PU vir CHO 1958.

B J van der Walt, Wat is Christelike wetenskap?, Perspektief 4,4, Maart 1966 p 3-13 \& 5,1, Junie 1966 p 2-13.

$B$ J van der Walt, Wat is die verskil tussen 'n Christelike en nieChristelike wetenskap?, Bulletin van die S A V CW 16, Nov 1968 p 266-274.

B J van der Walt, The encounter of Arabic en Christian civilizations in Mediaeval philosophy with particular reference to the conflict between faith and reason, Bulletin van die S A V CW 23 , Julie 1972 p 53-64.

B J van der Walt, Athene en Jerusalem: metodes van sintese in hulle ontmoeting, Tydskrif vir Christelike Wetenskap9, 1973 p 1542

B J van der Walt, Eisegesis - exegesis paradox and nature-grace methods of synthesis in Mediaeval Philosophy, Philosophia Reformata 38, 1973 p 191-210.

B J van der Walt, "In lumine Tuo videbimus lumen": Integral Christian Scholarship, Fort Hare Papers 6, Nov 1974 p 63-79.

$B$ J van der Walt, Natuurlike Teologie met besondere aandag aan die visie daarop by Thomas van Aquino. Johannes Calvyn en die "Synopsis Purioris Theologiae" - 'n wysgerige ondersoek, Potchefstroom, Proefskrif PU vir CHO 1974/75.

$\mathrm{J} M$ van Minnen, Slaat het Calvinisme de brug tussen geloof en natuurwetenschap? Ad Fontes 6, 6, Mrt 1959 p 168 ev.

C A van Peursen en $\mathbf{R}$ Hooykaas, Geloof en wetenschap, In Christelijke Encyclopedie III, Kampen, Kok 1959 p 140-144.

H Van Riessen, Wetenschap, In: Christelijke Encyclopedie VI, Kampen, Kok 1961 p 602-604.

H van Riessen, Die Christenstudent - zijn wetenschap, zijn gesprek, Delft, Naamlose Vennootschap 1947.

H van Riessen, Geloven en studeren, Mededelingen van de Vereniging voor Calvinistische Wijsbegeerte Mei 1956 p 2-4

$H$ van Riessen. The relation of the Bible to Science, In Christian Perspectives 1960, Pella Iowa, Pella Publishing 1960 p 3-56.

$H$ van Riessen, De Christen en zijn werk \& De Christenacademicus en de wetenschap, In: Mens en werk, Amsterdam, Buijten en Schipperheijn 1962

$H$ van Riessen, The University and its basis, St Catherines, Ontario, The Association for Reformed Scientific Studies 1962.

D J van Rooy, Beskrywing en verklaring in die natuurwetenskap, Koers 23, 1955/'56 p 200 ev.

D J van Rooy, Christelike Hoër Onderwys en Christelike wetenskap, Die Gereformeerde Vaandel 15, 12, Des 1947 p 8 ev.

E G van Teylingen, Is Christelijke wetenschap Christelijke beoefening van wetenschap of wetenschapsbeoefening door Christene? Schering en Inslag 9,3, Mrt 1960 p 74. 
E A Venter, Die gelowige en die samelewing, Bloemfontein, SACUM.

E A Venter, Wysgerige temas, Bloemfontein, SACUM s j.

Verslag van die Studenteraadskommissie van die PU vir $\mathrm{CHO}$ van ondersoek in sake Christelike Wetenskap (Ogestel Aug 1974, gepubliseer 1975)

D H Th Vollenhoven, Religie en gelnof, Mededelingen van de Vereniging voor Calvinistische Wijsbegeerte Des 1953 p 1-3

D H Th Vollenhoven, Getuigen in de wetenschap, Sola Fide 12, 3 , 1959 p 1 -3.

D H Th Vollenhoven, Het geloof, zijn aard, zijn structuur en zijn waarde voor de wetenschap, In: Levensbeschouwing en lewenshouding van de academicus, Utrecht-Nijmegen, $\mathrm{N}$ V Dekker en Van de Vegt $1950 \mathrm{p}$ 71-77.

P W Vorster, Die noodsaaklikheid van 'n Christelike Universiteit, Die Gereformeerde Vaandel 5, 1937 p 89-92.

J H Vrieling, De mogelijkheid van "Christelijke" wetenschap, Ad Fontes 7, 10 Aug/Sept 1960 p 307 ev.

J D Vrey, Kan wetenskap neutraal wees?, Tydskrif vir Christelike Wetenskap 1, 1, Mei 1965 p $25 \mathrm{ev.}$

J Waterink, Neutrale wetenschap, Bulletin van die S A VCW 1,2, Aug 1965 p 46-53.

$S U$ Zuidema, Christelijk Studeren, Mededelingen van de Vereniging voor Calvinistisch Wijsbegeerte Sept 1955 p 3-5. 